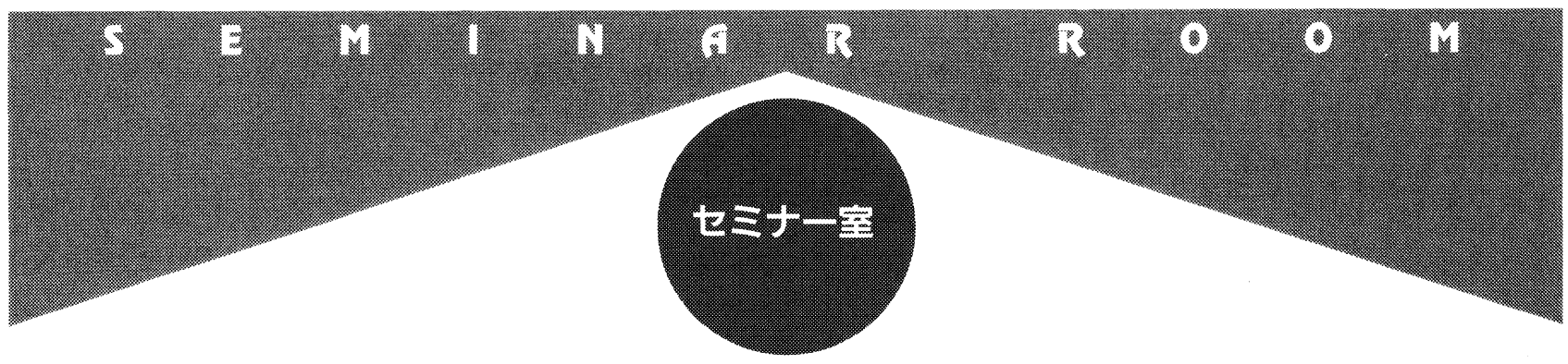

硝酸イオンの輸送・同化のバイオテクノロジー-3

\title{
硝酸還元酵素の遺伝子および活性発現の制御機構
}

\section{末吉 邦}

新潟大学農学部

植物は地球上の窒素循環の中で，無機窒素の吸収・同 化という重要な役割を担う。陸域の植物が 1 年間に同化 する窒素は, 10 数億トンと見積もられており，そのほと んどは土畩から吸収した無機窒素からの同化量であ $る^{(1)}$. 土壌への無機窒素の供給源は, 主として動植物の 遺骸，動物の排泄物といった有機物であるが，耕作地で はさらに窒素質肥料が加わる．有機窒素は土の中の微生 物によって分解され, $\mathrm{NH}_{4}{ }^{+}$として放出される. 多くの 窒素質化学肥料は土壤に投入されると, これらも $\mathrm{NH}_{4}{ }^{+}$ として遊離する。植物は, 基本的にこの $\mathrm{NH}_{4}{ }^{+}$を吸収・ 同化することが可能なのだが，常に空気に触れている普 通の土袞では, 硝化細菌の働きで $\mathrm{NH}_{4}{ }^{+}$は速やかに $\mathrm{NO}_{3}{ }^{-}$一と酸化される.したがって, そのような土地で育 つ植物にとっての無機窒素源は, 主として $\mathrm{NO}_{3}{ }^{-}$という
ことになる。

土褰中の窒素存在量は, 植物の生育を大きく左右す る. 我々人類は，土壌に不足しがちな窒素を有機あるい は化学肥料という形で補い, 作物生産量を大幅に増やし てきた. しかし, 窒素質化学肥料や有機物（特に畜産廃 棄物）が畑地へ過剩に投入されると, 大量に生成した $\mathrm{NO}_{3}{ }^{-}$が水とともに地下水に流れ込む. また植物は, 自身 の還元能を上回る $\mathrm{NO}_{3}{ }^{-}$を吸収すると, これを未還元の まま体内に貯めてしまう. $\mathrm{EU}$ 諸国では, 野菜の $\mathrm{NO}_{3}{ }^{-}$含 量は $2,500 \sim 4,500 \mathrm{ppm}$ に厳しく規制されている(2).こ れは野菜からの過剰な $\mathrm{NO}_{3}{ }^{-}$摂取が, 健康上よくないと されているからである.このように, 窒素質化学肥料や 含窒素有機物から放出される $\mathrm{NO}_{3}{ }^{-}$が, 環境や作物の品 質に与える影響が懸念されている地域もあれば，経済的 
な問題で十分な窒素が耕地に投入できず，作物の増産が いまだ困難な地域もある。

前述したように，植物にとって主要な無機窒素源は $\mathrm{NO}_{3}{ }^{-}$であるが, この窒素の効率的な吸収・同化を図るこ とは, 窒素供給の過剰な地域, 不足した地域のどちらに も共通した課題であろう. しかし, 植物の $\mathrm{NO}_{3}{ }^{-}$同化の 栄養生理についてはまだ不明な部分が多い。本稿では, 植物の $\mathrm{NO}_{3}{ }^{-}$同化に重要な硝酸還元酵素(NR)について, その遺伝子と活性の発現制御機構の仕組みを解説しつ つ, NRのバイオテクノロジーの可能性についても述べ てみたい。

\section{NRとはどのような酵素か}

まずNRの一般的性質について簡単に触れておく．生 化学的な性質は前号で詳しく解説されているので, そち らを参照していただきたい。

植物の NR にはアイソザイムがあり，NADH を電子 供与体とする NADH-NR と, NADH と NADPH の両 方を利用できる $\mathrm{NAD}(\mathrm{P}) \mathrm{H}-\mathrm{NR}$ がある。一般に, 双子葉 植物では NADH-NR のみが根と葉で発現している。一 方, 単子葉植物は両方の NR をもち, NADH-NR は根と 葉で, NAD $(\mathrm{P}) \mathrm{H}-\mathrm{NR}$ は根でのみ活性が認められる。い ずれの $\mathrm{NR} も \mathrm{NO}_{3}$-で de novo に合成が誘導される. 特 殊な例をいくつか挙げると, ダイズは $\mathrm{NO}_{3}{ }^{-}$誘導性の NADH-NR に加元, 構成的に発現しているNADH-NR と $\mathrm{NAD}(\mathrm{P}) \mathrm{H}-\mathrm{NR}$ の全部で 3 つのアイソザイムをも つ.また, カバ (Birch)の木は $\mathrm{NAD}(\mathrm{P}) \mathrm{H}-\mathrm{NR}$ だけを もつ.チコリ (Chicory) は根にのみ NADH-NR 活性が あり，葉では活性がほとんど検出されない。このような NR の器官特異的な発現を決定づける仕組みは，今も明 らかになっていない.

NR 活性の強さは, 植物種あるいは品種間でまちま ちであるが，これは遺伝的に決められているらしい。 $\mathrm{NAD}(\mathrm{P}) \mathrm{H}-\mathrm{NR}$ の活性は，オオムギの場合 $\mathrm{NADH}-\mathrm{NR}$ の $10 \%$ 以下にすぎないが，この酵素が $\mathrm{NO}_{3}{ }^{-}$還元にどれ だけ寄与しているかは十分調べられていない. NRは, 根では表皮および皮層細胞の, 葉では葉肉細胞の細胞質 に存在する。一般に, 葉での活性が根よりも数倍から 10 倍ほど高い.すでに 20 種あまりの植物から, NR 遺伝 子が単離され塩基配列も決定されたが，異なる植物種に 由来する NRのアミノ酸配列レベルでの相同性は 70 80\%とかなり高い.

\section{植物個体内での硝酸イオンの動き}

ここで， $\mathrm{NR} の$ 基質となる $\mathrm{NO}_{3}{ }^{-}$が植物体内でどのよ うに動くのか述べておきたい. $\mathrm{NO}_{3}{ }^{-}$は水への溶解度が 高いうえ，植物細胞に対する毒性も低いので，輸送や貯 蔵に適した物質といえる. $\mathrm{NO}_{3}{ }^{-}$が体内を動くときに制 約を受けるのは, 細胞膜と液胞膜を横切るときである. 培地の $\mathrm{NO}_{3}{ }^{-}$は根の細胞膜上にある能動的輸送体の働き で細胞内に取り込まれ，原形質連絡で導管の周りにあ る柔細胞に送られる（図 1)。一部の $\mathrm{NO}_{3}{ }^{-}$は，その途上 で根の硝酸還元系で還元・同化されるか，液胞に取り込 まれ貯蔵される，オオムギの場合，根の細胞内 $\mathrm{NO}_{3}{ }^{-}$濃 度は細胞質が $5 \mathrm{mM}$ ，液胞では $50 \sim 70 \mathrm{mM}$ である ${ }^{(3)}$. 細 胞質の $\mathrm{NO}_{3}{ }^{-}$濃度は, 培地からの吸収と液胞からの供給 とのバランスで一定に保たれている．しかし，液胞と細 胞質間の $\mathrm{NO}_{3}{ }^{-}$輸送に関わる因子はまだ同定されていな い.

柔細胞に移動してきた $\mathrm{NO}_{3}{ }^{-}$は，導管へ放出され水と ともに葉へ送られる。土䁃溶液中の $\mathrm{NO}_{3}{ }^{-}$濃度は, 施肥 や溶脱などの影響を受け, 数十 $\mu \mathrm{M}$ から十 $\mathrm{mM}$ ほどの範 囲で常に変動している. しかし，植物はそのような培地 の $\mathrm{NO}_{3}{ }^{-}$濃度変化(特に低濃度の場合)に対しても，導管 液中の $\mathrm{NO}_{3}{ }^{-}$濃度を一定以上 (10 mM 以上) に保ってい るようである，たとえばオオムギでは，根に低濃度 $(100$ $\mu \mathrm{M})$ の $\mathrm{NO}_{3}{ }^{-}$を与えたときでも，導管液中の $\mathrm{NO}_{3}{ }^{-}$濃度 は $20 \mathrm{mM}$ もある.この場合 $\mathrm{NO}_{3}{ }^{-}$は，培地から導管に たどり着くまでに，実に 200 倍にも濃縮されたことにな る．導管は死細胞が連なったパイプのようなものである から，それ自身が導管液の $\mathrm{NO}_{3}{ }^{-}$濃度を調節していると は考えられない。導管液中の $\mathrm{NO}_{3}{ }^{-}$濃度は, 柔細胞から 導管への放出の段階で調節されているのだろう (図 1). 後でも述べるが，導管における $\mathrm{NO}_{3}{ }^{-}$の濃縮効果は，葉 における NR 遺伝子の発現に重要な意味をもつ.

葉に到達した後の $\mathrm{NO}_{3}{ }^{-}$の挙動もあまりわかっていな い. $\mathrm{NO}_{3}{ }^{-}$は, 導管から葉の維管束組織の細胞外空間(ア ポプラストという)に放出され，葉の細胞に吸収される。 ここでも細胞膜を横切る輸送が必要となるが, ここで葉 と根における窒素環境の違いに注意されたい。つまり， 根は培地の $\mathrm{NO}_{3}{ }^{-}$濃度変化にさらされているのに対し, 葉は高濃度の $\mathrm{NO}_{3}{ }^{-}$供給を常に受け続けているというこ とである．根では $\mathrm{NO}_{3}{ }^{-}$に対し親和性の異なる複数の能 動輸送体が発現していて， $\mu \mathrm{M}$ から $\mathrm{mM} レ$ レルの広い濃 度範囲の $\mathrm{NO}_{3}$ - 吸収に対応していると考元られるが，葉 ではそれらとはまったく別の $\mathrm{NO}_{3}{ }^{-}$輸送体を考えるべき かもしれない，実際，これまで調べられた $\mathrm{NO}_{3}{ }^{-}$輸送体 


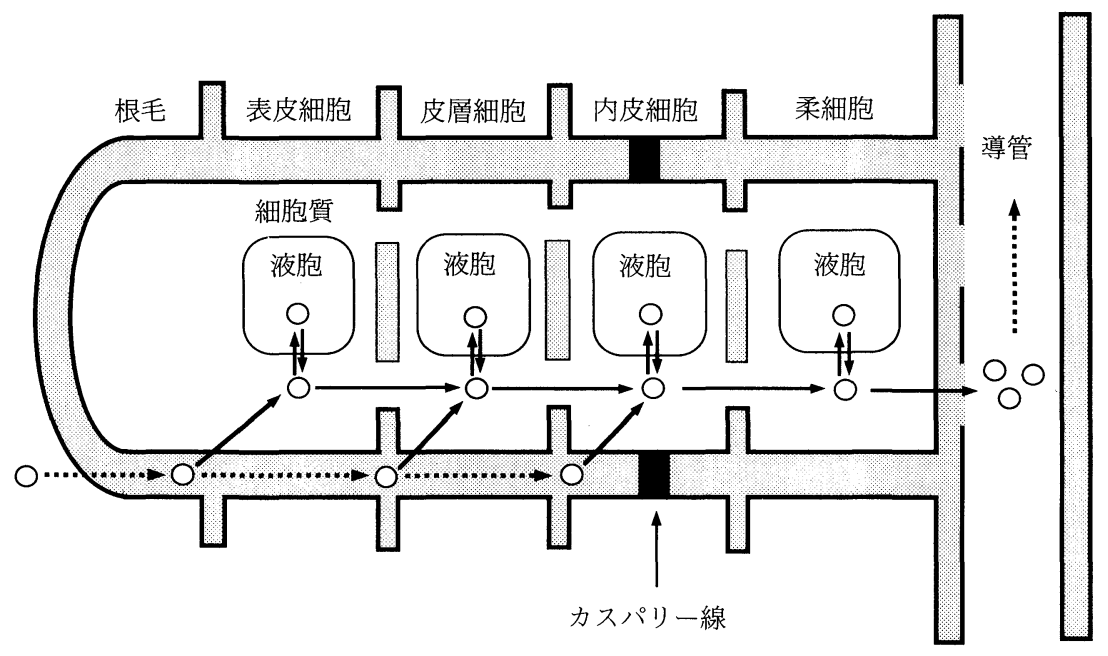

図 1 ・根内部における $\mathrm{NO}_{3}$-の動き

$\mathrm{NO}_{3}{ }^{-}$(○で示す) は, 細胞内に吸収された後原形質連絡を通って導管柔細胞まで達するか (実線の矢印), 細胞壁や細胞間隙をマスフロー と拡散によって不透水性のカスパリー線の外側まで移動した後に(破線の矢印), 皮層細胞内に吸収されて導管柔細胞まで運ばれる.最終的 に $\mathrm{NO}_{3}{ }^{-}$は柔細胞の細胞膜を横切って, 導管へと放出される.

遺伝子（候補も含めて）は，葉ではほとんど発現してい ない. 葉の細胞に取り込まれた $\mathrm{NO}_{3}{ }^{-}$は, 根の場合と同じ く還元・同化されるか，液胞に蓄えられる，このように， 体内における $\mathrm{NO}_{3}{ }^{-}$の動きを追っていくと, 実に様々な $\mathrm{NO}_{3}{ }^{-}$輸送体を想定しなければならない.それらの分 子実体と制御機構は, 今後明らかにすべき重要な課題で ある。

\section{NR 遺伝子の転写レベルでの制御}

NRの mRNA レベルは内的・外的な要因でダイナミ ックに変動する. 特に顕著に影響する因子は, $\mathrm{NO}_{3}{ }^{-}$, 光 そして同化窒素である.では, mRNAレベルの変動がど のようにNRタンパク質量の変化として現われるのか を考えてみたい. RNA 合成阻害剤を用いた害験から， NR mRNA の半減期はおよそ 1 時間と見積もられた。こ れはフィトクロムの mRNA に匹敵するほど短い部類に はいる.したがって, NR mRNA は, NR 遺伝子の転写 が停止させられると細胞内から速やかに消失していく. $\mathrm{NR}$ タンパク質の半減期もまた 4 6 時間と短いので, NR タンパク質は新たな mRNA の供給がないと, 10 時 間ほどでほぼ完全に分解されてしまう。一方, NR mRNA の合成量が増加した場合は, 数時間遅れで NR タンパク質量が上昇してくる. 以下に, NR 遺伝子の発現 制御に関わる主要な因子について概説する.

\section{1. $\mathrm{NO}_{3}$-による制御}

$\mathrm{NR}$ 活性が $\mathrm{NO}_{3}{ }^{-}$によって誘導される現象は古くから 知られていたが，その分子機構はそれほどわかっていな い.この誘導は, $\mathrm{NR}$ 遺伝子の転写が $\mathrm{NO}_{3}{ }^{-}$によって活 性化されることに基づく. 植物細胞は, $\mathrm{NO}_{3}{ }^{-}$の存在を 検知してはじめて NR 遺伝子の転写を活性化するわけ であるが, その仕組みは今のところまったくわかってい ない. $\mathrm{NO}_{3}{ }^{-}$が細胞の外と内側の, どちらで誘導因子と して機能しているのかさえもまだ明らかでない.一方, $\mathrm{NO}_{3}{ }^{-}$が検知されると, その情報は核へ伝えられなけば ならない.このシグナル伝達過程に関しては, 細胞内へ の $\mathrm{Ca}^{2+}$ 流入と細胞内因子のリン酸化・脱リン酸化が必 要であると考えられている ${ }^{(4,5)}$. シグナル伝達の最終段階 は, 転写制御因子が NR 遺伝子上流のシス領域に結合 し, 転写を活性化することにある. Cheng らによって, $\mathrm{NO}_{3}{ }^{-}$シグナルに応答するシス配列として $\mathrm{A}(\mathrm{G} / \mathrm{C}) \mathrm{TCA}$ が候補にあげられたが，その部分に結合しうるタンパク 質因子はまだ発見されていない.

培地に $\mathrm{NO}_{3}$-を与えると, 根と葉でほぼ同時に NR 遺 伝子の転写が起こる. $\mathrm{NO}_{3}{ }^{-}$の効果は, $\mathrm{NH}_{4}{ }^{+}$や他の窒 素化合物では代替できないので, $\mathrm{NR}$ の誘導は $\mathrm{NO}_{3}{ }^{-}$特 異的である。このとき培地に与えられる $\mathrm{NO}_{3}$-濃度は $\mu \mathrm{M} レ$ レルで十分であるが, 同時に葉においても $\mu \mathrm{M} レ$ ベルの $\mathrm{NO}_{3}{ }^{-}$が検知されているわけではないようであ る. 前述したように, 葉は導管から常に高濃度の $\mathrm{NO}_{3}{ }^{-}$ 供給を受けている，ということは，葉における $\mathrm{NO}_{3}{ }^{-}$の 検知機構もまた吸収機構と同じく根と異なることが予想 


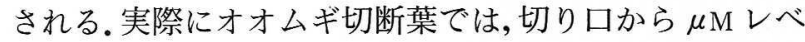
ルの $\mathrm{NO}_{3}{ }^{-}$を吸わせても NR mRNAの蓄積は起こら ず, $\mathrm{mM}$ レベルの $\mathrm{NO}_{3}{ }^{-}$を吸わせることではじめて $\mathrm{NR}$ mRNA の蓄積が起こる (末吉ら，末発表)。このことは， $\mathrm{NO}_{3}$ - が導管を介して高濃度に輸送されることがなぜ重 要であるのかを示している.

さらに，葉における NR mRNA レベルと導管液中の $\mathrm{NO}_{3}{ }^{-}$濃度との関係を詳細に比較すると, お互いが密接 な関係にあることがわかった（図 2)。葉で NR 遺伝子の 転写のスイッチが入るためには，導管液中に $\mathrm{NO}_{3}{ }^{-}$が少 なくとも数 $\mathrm{mm}$ 以上あることが必要なようである。一 方, 組織の $\mathrm{NO}_{3}{ }^{-}$蓄積量は, $\mathrm{NR}$ mRNA レベルに反映す るような顕著な変化を示さない ${ }^{(6)}$.これらのことから， 葉における NR 遺伝子の発現制御の要因は, 細胞内に蓄 積した $\mathrm{NO}_{3}-$ ではなく，導管とそれにつながるアポプラ ストの $\mathrm{NO}_{3}{ }^{-}$にあるのではないかと考えられ，現在詳し い検討がなされている.

\section{2. 同化窒素による制御}

硝酸同化の初期産物であるグルタミンやアスパラギ ン(アミドという)が細胞内に集積すると，NR 遺伝子の 発現は強く抑制される ${ }^{(7)}$. 夕バコやトマトでは, NR mRNA 量と体内グルタミン含量は互いに逆の関係を示 す.アミドが NR 遺伝子の発現を強く抑制するというこ とは, エネルギー消費を伴う $\mathrm{NO}_{3}{ }^{-}$還元を不必要に進行 させないという点では理屈にかなう．アミドによる NR 遺伝子発現の抑制に働くシグナルの実体は，アミドその ものなのか，あるいはそれらの代謝産物なのかはまだわ からない。もしかしたら, 細胞内の炭素/窒素比の変化 が引き金になっているのかもしれない.

\section{3. 光による制御}

緑化したオオムギ葉では，NR 遺伝子の発現が $\mathrm{NO}_{3}{ }^{-}$ によって活性化されるときに強い光（白色光）が与えら れると発現量が増幅される。一方, 黄化葉のオオムギ牙 生えでは赤色光あるいは青色光が重要で，このときには 光受容体であるフィトクロムが関与しているらしい. 生 理的には土の中から芽が出てきたときにフィトクロムの 働きが重要なのだろうか. シロイヌナズナでは, スクロ 一スを与えると暗所でも NR 遺伝子の発現が活性化さ れることから, 光の効果は何らかの炭酸同化産物を介し ても行われていると考えられる。また，タバコやトマト の NR mRNA は，暗期の終わりに蓄積量が最大にな り, 明期の終わりにはほとんど検出されない。活性はこ れに数時間遅れて変動するので，結果的に NR 活性は,

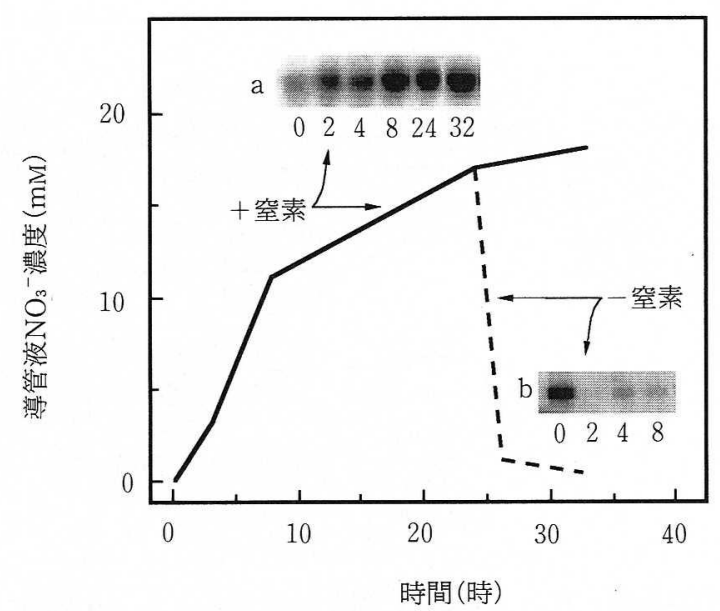

図 2 導管液中の $\mathrm{NO}_{3}$ - 濃度と葉における $\mathrm{NR}$ mRNA レべ ルとの関係

無窒素で育てたオオムギ幼植物に, $1 \mathrm{mM} \mathrm{NO}_{3}{ }^{-}$を 32 時間与え続け たとき (十窒素)，あるいは $\mathrm{NO}_{3}{ }^{-}$を 24 時間与えてから無窒素培養 液に移したとき (一窒素) の導管液中の $\mathrm{NO}_{3}{ }^{-}$濃度（実線と波線） と，葉に扔ける NR mRNA レべル $(\mathrm{a} と \mathrm{~b})$ を測定した， a および $\mathrm{b}$ に付した数字は，処理後の時間を示す。

明期の初期に最大になり，暗期の後期に最小になる．実 はこれは，NR 遺伝子の発現自身が日周リズムをもって いるのではなく, NR 遺伝子の発現を抑制するグルタミ ンの体内含量が NR mRNA と正反対の日周リズムをも つことに起因している.

\section{NR の翻訳後の制御}

NR 活性は，翻訳後のレベルでも様々な要因によって 制御を受ける。この制御もまた非常に複雑であるが, 解 析の進んでいるいくつかの現象を取り上げて解説した い.

\section{1. 光による制御}

90 年代初頭 Kaiser らは，ホウレンソウの切断葉を明 所から暗所に移したときに，NR 活性がわずか数分で約 半分に減少し, 再び明所に戻すと数時間で元の值まで活 性が回復することを初めて報告した．その後の数年の間 に, Kaiser らを含めた数グループの努力によって, NR の不活性化機構の全容がほぼ明らかにされた ${ }^{(8)}$.それ は，植物を暗所におくと NR は直ちにリン酸化され，そ れに続いて 14-3-3 タンパク質（14-3-3）がリン酸化 NR に結合して，NR を失活させるというものである(図 3). 植物を明所に戻すと, NR は脱リン酸化され, 同時に 14-3-3 がはずれ再活性化される．NR 遺伝子の転写レべ ルでの制御が NR 活性に反映されるのに, 数時間から 10 時間程度かかることからすると, リン酸化・脱リン酸化 


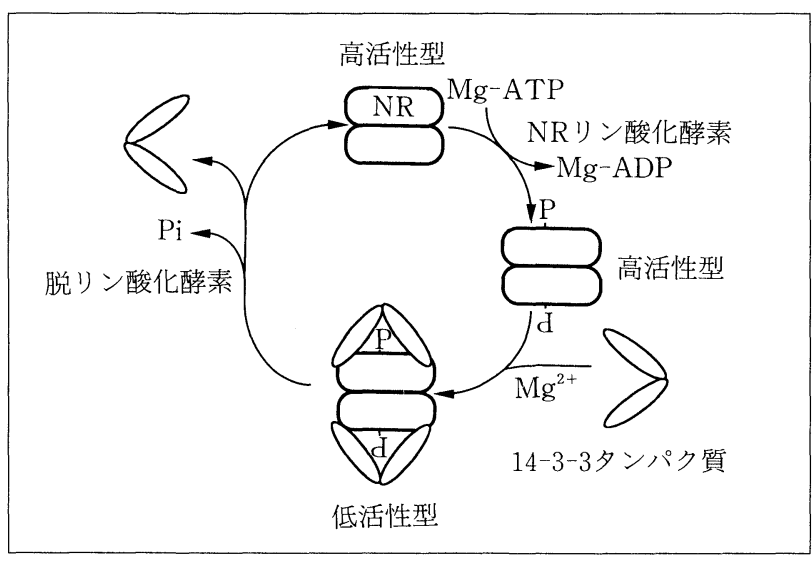

図 3 ・明暗移行に伴うリン酸化・脱リン酸化によるNRの可 逆的な活性制御

$\mathrm{P}$ は NR に付加されたリン酸基を表わす。暗処理によってリン酸化 された NR は，14-3-3 タンパク質の結合によって完全に失活する のではなく, 20〜 40\%の残存活性がある.

による NR 活性の制御がいかに早いかがわかる.

この現象の生理的意義は次のように考えられている. $\mathrm{NO}_{3}{ }^{-}$還元によって生じた $\mathrm{NO}_{2}{ }^{-}$は, 葉緑体に運ばれ巠 硝酸還元酵素 $(\mathrm{NiR})$ によって還元される. $\mathrm{NiR}$ は, $\mathrm{NO}_{2}{ }^{-}$ の還元に光合成電子伝達系で生成する還元型フェレドキ シンを必要としていて，暗所ではこのフェレドキシンの 供給がすぐに減少してしまう。もし NR 活性が暗所でも そのままであれば，細胞内の $\mathrm{NO}_{2}{ }^{-}$が急速に有毒な濃度 に達するであろう。したがって，NR が暗所で活性が抑 えられるのは, 有毒な $\mathrm{NO}_{2}{ }^{-}$の蓄積をさけるための機構 というわけである.

これまでに，試験管内で NR をリン酸化しうる酵素と して, $\mathrm{Ca}^{2+}$ 依存性のリン酸化酵素が 2 種, $\mathrm{Ca}^{2+}$ を必要 としないSNF (sucrose non fermenting)1 様リン酸化 酵素が 2 種見つかっている，それらの中には，自身の活 性発現もまたりン酸化で制御されているものもあって, 複雑な様相を呈している.これらのリン酸化酵素は, NR の $\mathrm{N}$ 末端から 543 番目（ホウレンソウの場合）のセリン 残基を特異的にリン酸化する.このセリンは，モリブデ ンコファクタードメインとシトクロムドメインとを結ん でいるヒンジ-1 領域にある(前号参照)。しかし，NR は リン酸化されただけでは失活せず,続けて 14-3-3 が結合 してはじめて失活する。

14-3-3 は, 約 $30 \mathrm{kDa}$ の同一サブユニット 2 つが会合 したホモダイマーである.14-3-3 は初めウシの脳から 見いだされた. 動物細胞では 14-3-3 は Raf-1 タンパク 質, プロテインキナーゼ C やチロシン水酸化酵素などに 結合し，それらを活性化あるいは不活性化する，標的夕 ンパク質には 14-3-3 の結合に必要な共通のアミノ酸配
列, $\mathrm{R}(\mathrm{K})-\mathrm{S}-\mathrm{X}-\underline{\mathrm{S}}-\mathrm{X}-\mathrm{P}($ アミノ酸の 1 文字表記, $\mathrm{X}$ は任 意) が保存されていて，14-3-3 が結合するためには，こ の配列の中の下線で示したセリン残基（NRの場合は 543 番目)がリン酸化されなければならない.つまり,リ ン酸化酵素と 14-3-3 は NR の共通する部位に作用して いることになる. 14-3-3 は NR との結合に mM レベル の $\mathrm{Mg}^{2+}$ を必要とし, NR 1 分子に対し 2 分子結合する らしい(図 3). また，14-3-3 は多重遺伝子族にコードさ れていて, シロイヌナズナやトマトでは 10 個もアイソ フォームがある．お互いのアミノ酸配列レベルでの相同 性は $80 \%$ 以上と高く, 程度の差はあれ，どの分子種も NR に作用しうると思われる.作用の特異性は, 細胞内あ るいは組織の局在性によっても決められているのかもし れない.

不活性化された NR は, 脱リン酸化酵素によってリン 酸基がはずされ，再活性化する，生理的には脱りン酸化 のシグナルは光の再照射であるが，脱リン酸化酵素その ものについては，2A 型であるということ以外はほとん ぞわかっていない.

リン酸化酵素，14-3-3，そして脱リン酸化酵素のいず れも明暗に関わりなく存在するので, これらの存在量 そのものが光環境に応答して調節されていることはな い. では, リン酸化反応に必要な ATP や $\mathrm{Ca}^{2+}$ ，そして 14-3-3 と NRの結合に必要な $\mathrm{Mg}^{2+}$ などの細胞内濃度 が，明暗変化で変動するのかというと，その確たる証拠 も今のところない. 試験管内の実験ではあるが，グルコ ース-6-リン酸やフルクトース-1, 6-二リン酸などは NR のリン酸化酵素を，また AMP は 14-3-3 とリン酸化 NR の結合を阻害することが確かめられている．これら の細胞内レベルが明暗移行の際に変化するのかもしれな い. 炭素代謝における主要酵素の一つであるスクロース リン酸合成酵素 (SPS) も，暗所でリン酸化され不活性化 する，興味深いことに，NRのリン酸化酵素はSPS の リン酸化も可能なことが報告された。さらに最近にな って，14-3-3 は SPS をはじめ, グルタミン合成酵素, トレハロースリン酸合成酵素などとも結合することが Macintosh らによって示された ${ }^{(9)}$.これらのことは, 窒 素と炭素の代謝間の相互調節が, 翻訳後レベルでも行な われていることを示唆しており，14-3-3 はその中心的な 役割を担っているのかもしれない.

\section{2. 基質および代謝産物による制御}

$\mathrm{NO}_{3}{ }^{-}$とその代謝産物である $\mathrm{NO}_{2}{ }^{-}, \mathrm{NH}_{4}{ }^{+}$およびアミ ドが，直接 NR の活性を制御しているという可能性は今 のところ少ない，ただトウモロコシやオオムギでは，組 
織の $\mathrm{NO}_{3}{ }^{-}$含量が高いほど $\mathrm{NR}$ は安定, つまり分解され にくいとの報告もある.また, $\mathrm{NO}_{3}^{-}$と $\mathrm{NADH}$ に対する $\mathrm{NR}$ の $K_{\mathrm{m}}$ 值は，それぞれ $300 \mu \mathrm{M}$ と 5 10 $\mu \mathrm{M}$ 程度であ るが，これらの細胞質濃度が NR 活性の制限要因となっ ているという可能性もあるであろう。しかし，少なくと もオオムギ根では, 細胞質 $\mathrm{NO}_{3}{ }^{-}$濃度は $5 \mathrm{~mm}$ と $K_{\mathrm{m}}$ 值 より十分に高いので, $\mathrm{NO}_{3}{ }^{-}$が $\mathrm{NR}$ 活性の制限要因とは なっていないはずである。一方の基質である NADH が NR の最大活性に見合う量が供給されているかどうかも 重要である. 細胞質の NADH 濃度についての正確なデ ータはないので何ともいえないが，NADH を還元力と して用いる酵素は細胞質に多数存在するため，それらと の競合も考慮する必要があろう。

\section{3. タンパク質分解による制御}

先にも触れたように，NR タンパク質の半隇期は $4 \sim 6$ 時間と短い. NR の分解に関する研究は一時期活発に行 なわれ，トウモロコシやオオムギからは NR 特異的に作 用するプロテアーゼが精製された，当時の精製 NR に対 する作用機作のデー夕をみると，それらのプロテアーゼ は, NRの 3 つのドメインの間にあるヒンジ領域と呼ば れる部分を切断しているのではないかと推測できる. 前 号の NR の構造を参照していただくとよくわかるが，こ の 2 つのヒンジ領域はドメイン間を結ぶ紐のようなもの で, 切断を受けやすいのであろう. 事実, 精製 NR に V8 プロテアーゼやトリプシンを作用させると，この部分が 特異的に切断される。おそらく NR は, 細かなぺプチド 断片に分解される前に, このヒンジ領域で限定的に切断 されて失活するものと思われる. 実際，ホウレンソウ緑 葉の抽出液を抗 NR 抗体カラムに通して結合したタン パク質を分析してみると，ヒンジ-2 領域が切断されて生 じたと思われるポリペプチド断片すなわち分解中間体が 得られた。このヒンジ領域のアミノ酸配列を改変して, 分解に対し安定な NR を創ることは可能ではないだろ うか.また， $\mathrm{N}$ 末端の約 50 残基を欠失するような $\mathrm{NR}$ を 生産する遺伝子組換えタバコから得られた NR は, 分解 に対して安定であるという興味深い研究もある ${ }^{(10)}$.ま た最近, 14-3-3 と複合体を形成した NR は分解されやす いという報告も出された ${ }^{(11)}$. 中川らは，ホウレンソウ緑 葉から超分子タンパク質分解酵素複合体であるプロテア ソームを見いだしており ${ }^{(12)}, \mathrm{NR}$ との関連が期待される.

\section{4. 光の他の不活性化因子による制御}

NR に結合して失活させるタンパク質因子が，中川ら によって精製された ${ }^{(13)}$.このタンパク質は, $\mathrm{Mg}^{2+}$ 依存

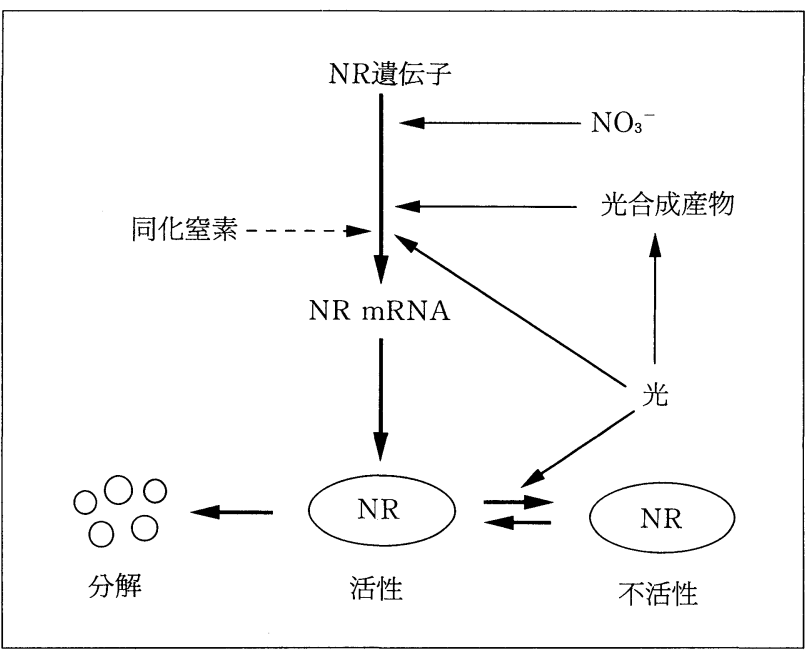

図 4-NRの遺伝子および活性発現の種々の因子による制御 実線の矢印は正の，波線の矢印は負の制御を示す。

的に NR に作用し，NR を高分子化させて不可逆的に失 活させるというきわめてユニークな機能をもっている. このタンパク質の cDNA はすでにクローニングされ, ヌ クレオチドピロホスファターゼであることがわかってい る.これが生体内で NR に対しどのように作用している のか, 今後の詳しい研究が待たれる.

\section{NRのバイオテクノロジーは可能か}

NR は硝酸同化速度を律速していると考えられてお り, NR の制御に関わる内的, 外的要因 (内的・外的窒素 栄養状態, 光, 制御タンパク質）も明らかになってきた (図 4).NR を含め, 硝酸同化に関わる酵素の遺伝子は すでに多くの主要作物から単離されており, バイオテク ノロジーの対象となりつつある。

硝酸同化のバイオテクノロジーで考えられることは,

(1) $\mathrm{NO}_{3}{ }^{-}$をよく吸収できる植物を創る.

(2)吸収した $\mathrm{NO}_{3}{ }^{-}$をよく同化できる植物を創る. という 2 点である. (1)については, 培地からの $\mathrm{NO}_{3}{ }^{-}$吸 収のメカニズムはよく調べられているし, 機能する輸送 体遺伝子も明らかになっているので, 今後バイオテクノ ロジーの対象になるであろう(前々号参照). しかし, 植 物体内での $\mathrm{NO}_{3}{ }^{-}$の動き, 特に液胞への蓄積, 導管を介 した葉への輸送, そして葉の細胞への吸収についての分 子機構も今後明らかにされなければならない. (2)につい ては，NR 活性が常に高められた植物を創るということ が容易に着想されよう。

すでに，NR 遺伝子が過剩発現するように遺伝子が組 換えられたタバコとレタスの解析がなされている. タバ 
コでは, NR 活性が 2 割から 5 割ほど高められており,さ らに野生株にみられるような $\mathrm{mRNA}$ の日周変動も消失 している.この植物は残念ながら乾物重, 全窒素含量お よびタンパク質含量は野生株とあまり変わらない.しか し, $\mathrm{NO}_{3}{ }^{-}$含量が最大 $50 \%$ 減少していたことは有望と思 われる。ところが，同じようなことをレタスに試みても， 葉の $\mathrm{NO}_{3}$-含量の著しい減少にはつながっていないよう である。一方，NR 活性が著しく減少させられた突然変 異株や遺伝子組換え植物の解析もなされている. 詳しい 解説は省くが，これらの植物は野生株の 10〜 50\%の NR 活性しかないが，生育速度，収量ともに野生株とほとん ど変わらない，この結果からすると，NR が硝酸同化の 律速因子であることに疑問をもつかもしれない. しかし これは, NR の暗所での不活性化の程度が弱められてい たり, タンパク質の安定性の増加などによって補償され た結果であって, NR が硝酸同化において重要な酵素で あることに変わりはないであろう。いずれにしても， $\mathrm{NR}$ のみを標的としたバイオテクノロジーで $\mathrm{NO}_{3}{ }^{-}$同化 効率を上げるのには，無理があるように思える。

窒素代謝は，炭素代謝と相互に調節しあいながら厳密 に制御されていることが明らかになりつつある. $\mathrm{NO}_{3}{ }^{-}$ は $\mathrm{NR}$ のみ゙なく $\mathrm{NO}_{3}{ }^{-}$輸送坦体, $\mathrm{NiR}$ などの硝酸同化 系遺伝子や，有機酸合成系遺伝子の転写も活性化す る ${ }^{(14)}$. また, 窒素と炭素代謝系において重要な酵素の活 性も，翻訳後制御によって相互に調節されている可能性 も示唆されている。これら関連する酵素の遺伝子発現と 活性制御をも含めて, 硝酸同化のバイオテクノロジーを 考えることが今後求められる.
謝辞：執筆の機会を与えて下さった千葉大学園芸学部 中川弘毅教 授, 研究に協力いただいた新潟大学農学部および神戸大学農学部の 方々に深く感謝いたします。筆者らの研究成果の一部は文部省科 学研究費補助金, 学術振興会「未来開拓学術研究推進事業」によっ ていることを付記します。

\section{文献}

本稿では原著論文の引用は最小限にとどめた. 興味のある方は, 以下の文献の中に引用されている原著論文をお読みいただきたい.

1) E.A. Paul \& F.E. Clark : "Soil Microbiology and Biochemistry", Academic press, 1988.

2) 森 敏: 栄養と健康のライフサイエンス, 3, 675 (1998).

3) A.J. Miller \& S.J. Smith : J. Exp. Bot., 47, 843 (1996).

4) H. Sakakibara, K. Kobayashi, A. Deji \& T. Sugiyama : Plant Cell Physiol., 38, 837 (1997).

5) K. Sueyoshi, T. Mitsuyama, T. Sugimoto, A. Kleinhofs, R.L. Warner \& Y. Oji : Soil Sci. Plant Nutr., 45, 1015 (1999).

6) K. Sueyoshi, A. Kleinhofs \& R.L. Warner : Plant Physiol., 107, 1303 (1995).

7) K. Sueyoshi, T. Sugimoto \& Y. Oji : "Plant Nutrition for Sustainable Food Production and Environment", Kluwer Academic Publishers, 1997, p. 851.

8) W.M. Kaiser, H. Weiner \& S.C. Huber : Physiol. Plant., 105, 385 (1999).

9) G. Morehead, P. Douglas, V. Cotelle, J. Harthill, N. Morrice, S. Meek, U. Deiting, M. Stitt, M. Scarabel, A. Aitekin \& C. Macintosh : Plant J., 18, 1 (1999).

10) L. Nussaume, M. Vincentz, C. Meyer, J-P. Boutin \& M. Caboche: Plant Cell, 7, 611 (1995).

11) H. Weiner \& W.M. Kaiser : FEBS Lett., 455, 75 (1999).

12) K. Fujinami, N. Tanahashi, K. Tanaka, A. Ichihara, Z. Cejka, W. Baumeister, M. Miyawaki, T. Sato \& H. Nakagawa: J. Biol. Chem., 269, 25905 (1994).

13) A. Sasaki, K. Okuo, T. Yoshimura, N. Sekino, T. Sato, N. Ogura \& H. Nakagawa: Phyiol. Mol. Biol. Plants, 1, 121 (1995).

14）榊原 均, 杉山達夫 : 蛋白質核酸酵素, 44, 2269 (1999).

\section{プロフィル}

山中 健生 (Tateo Yamanaka) 昭和 7 年 5 月 30 日生 $<$ 略歴 $>$ 昭和 30 年大阪大 学理学部生物学科卒業 $/ 35$ 年同大学大 学院博士課程生物化学専攻修了/同年同 大学理学部助手 $/ 43$ 年同助教授 $/ 57$ 年 東京工業大学理学部教授 $/$ 平成 2 年同大 学生命理工学部教授 $/ 5$ 年同大学を停年 退官 (同大学名誉教授), 日本大学理工学 部教授, 現在にいたるく研究テーマと抱 負 $>$ 独立栄養細菌の起源と進化, ならび にそれらの地球環境への関わり

山本勇 (Isamu Yamamoto) 昭和
24 年 8 月 31 日生 $<$ 略歴>昭和 47 年北 海道大学薬学部薬学科卒業 $/ 52$ 年同大 学大学院薬学研究科博士課程修了(薬博) $/ 53$ 年同大学薬学部助手/平成 3 年広 島大学理学部生物学科助教授, 現在にい たる.この間，昭和 $55 \sim 58$ 年米国ジョ ージア大学生化学科研究員 $<$ 研究テーマ と抱負 $>$ 細菌の嫌気呼吸系遺伝子とその 発現制御機構の解明. 環境の変化に挑む 細菌の能力の可能性を探り出したい<趣 味>畑作り

熟津 正夫（Masao Washizu） 昭和 28
年 12 月 1 日生 $<$ 略歴 $>1976$ 年東京大学 工学部電気工学科卒業 / 1981 年同大学 大学院工学系研究科電気工学専攻博士課 程修了(工博) /同年(株)東芝重電技術研 究所勤務 $/ 1987$ 年成䠛大学工学部電気 電子工学科助教授，同教授を経て，1996 年上り京都大学大学院工学研究科機械工 学専攻教授, 現在にいたるく研究テーマ と抱負>マイクロマシン工学・静電気工 学のバイオテクノロジーへの応用, 分子 操作に基づく生物学・生化学 <趣味 > 音 楽鑑賞 (古典派・ロマン派中心), 読書(中 国古典中心), 動物園巡り (哺乳類中心) 